\title{
Sabina Kwak
}

Badaczka niezależna

iD http://orcid.org/0000-0001-5761-1660

\section{„Rozdarty skafander" Rafała Wilczura O melancholii bohatera powieści Tadeusza Dołęgi-Mostowicza}

\author{
Rafał Wilczur's "Torn Suit" \\ On Melancholy of the Protagonist of \\ Tadeusz Dołęga-Mostowicz's Novels
}

Abstract: What happens to a person who has lost those dearest to them? How does a man act when, full of joy and hopes for the future, he is deprived of the company of his beloved wife and his only daughter when he least expects it? A study of such a case is found in Tadeusz Dołega-Mostowicz's 1936 novel Znachor [The Quack]. In her article, Sabina Kwak argues this novel is primarily an exploration of loss and mourning - of running away from oneself, the degradation of the "I," and the attempt to bury one's past. Kwak's analysis of the novel's plot focuses on the depiction of the progressive work of mourning and of the story-advancing events in Rafał Wilczur's life, from the loss of his family and his amnesia (the annihilation of the personality) to the restoration of his memory and, through that restoration, the gift of the ability to forgive. This approach allows the author to shed new light on this most cinematic of Mostowicz's novels, with the psychoanalytic reading uncovering a deeper layer of meaning.

Key words: the interwar period, psychoanalysis, The Quack, melancholy, Tadeusz Dołęga-Mostowicz

Streszczenie: Co się dzieje z człowiekiem, gdy traci bliskich? Jak się zachowuje, kiedy w najmniej spodziewanym momencie, pełen radości i nadziei na przyszłość, zostaje pozbawiony towarzystwa ukochanej żony i jedynej córeczki? Studium takiego właśnie przypadku zaprezentował w powieści, pochodzącej z roku 1936, Tadeusz Dołęga-Mostowicz. Autorka dowodzi, że powieść Znachor 
to przede wszystkim opowieść o stracie i radzeniu sobie z nią; o ucieczce od samego siebie, degradacji „ja”, grzebaniu przeszłości. Analiza fabuły utworu pod kątem postępującej pracy żałoby, a także przedstawienie napędzających akcję losów Rafała Wilczura - od utraty żony i dziecka, przez amnezję (anihilację osobowości), po odzyskaną wraz z łaską wybaczenia pamięć - pozwala spojrzeć badaczce na najbardziej filmową powieść autora Kariery Nikodema Dyzmy w nowy sposób. Lektura psychoanalityczna odkrywa jej drugie dno.

Słowa kluczowe: dwudziestolecie międzywojenne, psychoanaliza, Znachor, melancholia, Tadeusz Dołęga-Mostowicz

Jednym z najbardziej znanych bohaterów literackich okresu międzywojennego jest Rafał Wilczur - centralna postać dylogii Tadeusza Dołęgi-Mostowicza, opublikowanej pod koniec lat 30. XX wieku. Popularność tego najsłynniejszego w ówczesnej Polsce znachora przez lata podsycają kapitalne kreacje aktorskie - najpierw Kazimierza Junoszy-Stępowskiego, następnie Jerzego Bińczyckiego, którzy niebywale sugestywnie odgrywają postać zranionego mężczyzny, pogrążającego się $\mathrm{w}$ melancholii. $\mathrm{W}$ niniejszym tekście chciałabym się skupić na tym właśnie aspekcie powieści - melancholijnej reakcji Wilczura na utratę obiektu miłości - oraz procesie gojenia się zadanych mu ran: psychicznych, cielesnych i symbolicznych.

Autor Kariery Nikodema Dyzmy rozpoczyna druk Znachora pod koniec roku 1936 - w okresie „aktywizowania się ruchów społecznych, polaryzacji stanowisk politycznych, zagubienia $\mathrm{w} »$ wielości rzeczywistości« społecznej, narastającej niepewności jutra, konsekwencji wielkiego kryzysu"1. Opisany na kartach jego ostatnich książek znany warszawski chirurg to człowiek ze wszech miar spełniony - jest dyrektorem świetnie prosperującej kliniki, autorytetem medycznym podejmującym się operacji przez innych uznawanych za niemożliwe, jak go określają współpracownicy - geniuszem². Również jego życie osobiste wydaje się szczęśliwe - ma żonę Beatę i córkę Mariolę, które uwielbia, dla których żyje i pracuje (Z, s. 27). Poznajemy go w dniu ósmej rocznicy ślubu, ósmej rocznicy - jak myśli - „wspólnego życia niezakłóconego ani razu najmniejszą sprzeczką, najdrobniejszym

${ }^{1}$ J. Rurawski: Wstęp. W: T. DoŁĘGA-Mostowicz: Znachor. Profesor Wilczur. Łódź 1988, s. 13.

${ }^{2}$ T. DoŁęGa-Mostowicz: Znachor. Profesor Wilczur..., s. 24. W szkicu posługuje się następującymi skrótami: Z - Znachor, PW - Profesor Wilczur, po których podaję numer strony, lokalizując cytaty. 
sporem czy bodaj cieniem nieufności, za to ileż razy rozświetlonego tysiącem chwil i godzin radości, pieszczot, zwierzeń..." (Z, s. 27).

W powieści czytamy:

Auto stanęło przed piękną białą willą, niewątpliwie najładniejszą w całej Alei Bzów, a jedną z najelegantszych w Warszawie. Profesor Wilczur wyskoczył, nie czekając, aż szofer otworzy drzwiczki, wziął z jego rąk pudło z futrem, szybko przebiegł chodnik i dróżkę, własnym kluczem otworzył drzwi i zamknął je jak najciszej za sobą. Chciał Beacie zrobić niespodziankę, którą ułożył sobie jeszcze przed godziną, gdy pochylony nad otwartą klatką piersiową operowanego obserwował powikłany splot aort i wen.

W domu zamiast żony i córki znajduje jednak list pożegnalny. Beata informuje w nim męża o swoim odejściu, wyznaje, że tak naprawdę nigdy go nie kochała, a odkryła to w chwili, gdy na jej drodze stanął inny mężczyzna.

Nigdy nie byłam godna Ciebie - pisze. Nigdy nie sięgałam do Twego poziomu. Sam o tym wiesz aż nadto dobrze i jedynie Twojej dobroci przypisuję to, żeś zawsze starał się nie okazać mi tego, co jednak było ponad wszelką miarę dla mnie poniżające i dręczące. Otoczyłeś mnie zbytkiem i ludźmi swego świata. Zasypywałeś mnie cennymi prezentami. Ale ja widocznie nie byłam stworzona do takiego życia. Męczył mnie i wielki świat, i bogactwo, i Twoja sława i - moja nicość przy Tobie.

Z, s. 29

Informacja o odejściu żony pozbawia bohatera „racji i celu istnienia" (Z, s. 32), czuje się on „jak drzewo wyrwane z korzeniami" (Z, s. 38). Wychodzi z domu, zaczyna błądzić ulicami późnopaździernikowej Warszawy, aż na jego drodze staje jakiś nieznajomy pijaczek odznaczający się olbrzymią elokwencją, który po otrzymaniu kilkuzłotowego datku mówi:

Pozwól [...], hojny ofiarodawco, że w zamian i ja ofiaruję ci coś cennego. Myślę o swoim towarzystwie. Tak. Słuch cię nie myli, dobry człowieku. Możesz dostąpić tego zaszczytu. Noblesse oblige! Ja stawiam! Zmokłeś, sir, i przemokłeś na zimnie, pójdź do mej chatki i rozgrzej się przy mnie. Wprawdzie nie mam chatki, ale za to po- 
siadam wiedzę. Cóż znaczy jakikolwiek budynek w porównaniu $\mathrm{z}$ wiedzą?... A ja się nią chętnie z panem, mon prince, podzielę. Wiedza moja jest rozległa. Na razie mówię tylko o jej części topograficznej. Wiem mianowicie, gdzie się mieści jedyna knajpa, do której o tej porze człowiek dostać się może bez wyłamywania zamków i krat. Jedno słowo: Drożdżyk. Tu na rogu Połanieckiej i Witebskiej.

Postać ta, żywo przypominająca Szekspirowskiego Błazna z dramatu Król Lear ${ }^{3}$, pozwala profesorowi przytłumić myśli, zapomnieć na chwilę o nieszczęściu, które go dotknęło, udaje się więc z nowo poznanym człowiekiem pod wskazany adres. Wilczur, niczym tytułowy bohater tragedii mistrza ze Stratfordu, jest odtrącony przez najbliższych; to ktoś, kto oddał całą władzę rodzinie, stał się dobrowolnym niewolnikiem dwóch kobiet - żony i córki. W chwili gdy znikają, traci sens życia, fundament, na którym oparł całą swoją egzystencję. Spotkany na ulicy mężczyzna - Samuel Obiedziński próbuje mu $\mathrm{w}$ tej sytuacji uzmysłowić jego własne błazeństwo. Stwierdza, że "nie sztuka być kimś. Sztuka być niczym. Niczym, drobnym insektem za kołnierzem Opatrzności" (Z, s. 35), i wykpiwa powszechne przywiązanie do zaszczytów, honorów, ludzi, których nie da się poznać, choćby żyło się obok nich przez lata. Stan Wilczura podsumowuje zaś słowami:

Jeżeli zechcesz, maestro, dowiedzieć się, jak naprawdę wygląda szykowna dama, możesz ją podpatrzeć $\mathrm{w}$ łazience przez dziurkę od klucza. Sprawdzisz, powiedzmy, że ma zdezelowany biust i cienkie uda. Dowiesz się o niej czegoś nowego. Ale o jej istocie nie będziesz $w$ dalszym ciągu nic wiedział. Bo nawet gdy jest sama i zdejmuje skafander, w który się zawsze ubierała dla ciebie, ma pod spodem drugi, którego nie zdejmuje nigdy i który dla niej samej jest czymś nieprzeniknionym. Prawda? Oczywiście, są chwile, kiedy można komuś zajrzeć przez rękaw czy za kołnierz. Są to chwile katastrofy. Skafander się rozdziera, pęka, zjawiają się szczeliny i szparki. Ot... ot na przykład w takiej sytuacji, w jakiej ty jesteś teraz, wodzu! Przetoczyło się po tobie coś ciężkiego.

Obiedziński, jak Szekspirowski Błazen, próbuje sprowadzić lekarza na ziemię, ostudzić jego emocje i pomóc mu pogodzić się z losem.

${ }^{3}$ Związki z postacią z utworu Szekspira sugeruje już sam Mostowicz, gdy w drugiej części cyklu powieściowego Obiedziński, odwiedzając Wilczura, przedstawia się nazwiskiem autora Snu nocy letniej. 
Wytyka mu głupotę („Dno każdej tragedii to głupota” - mówi), wyszydza sentymentalność. Drwi i ironizuje, po czym, widząc reakcję Wilczura i jego pogłębiającą się apatię, mówi:

Tak to jest z kobietami... Jedna przyssie się do ciebie i wszystkie soki wyciągnie, inna obedrze cię z tego, co masz, trzecia oszuka na każdym kroku, albo i taka będzie, co cię wciągnie w szarzyznę, w powszednie błoto... Pranie, sprzątanie, pieluchy i takie rzeczy. Ot i życie... Ale to nieprawda, to wszystko od mężczyzny zależy. Jaki jest! Po jednym spłynie gładko, drugi jak postrzelony kot zakręci się, zapiszczy i zdycha, a taki jak ty, amigo?... Twardy musisz być. Jak wielkie drzewo. Gdyby cię z kory obłuskano, porósłbyś nową, gdyby ci gałęzie obcięto, wyrosłyby nowe... Ale ot, wyrwało cię z korzeniami z gruntu... Rzuciło cię na pustynię... [...] I siła nie pomoże, gdy oparcia nie ma. Grunt rozmiękł, rozpłynął się, przestał istnieć.

Błazen Obiedziński jest tu wyrazicielem idei o rozpadzie indywidualnego świata, uwidacznia, że wszystko stanęło na głowie wielki profesor, majętny i powszechnie szanowany, pije w knajpie z nieposiadającym niczego żebrakiem, z nich dwóch to ten drugi jest jednak szczęśliwszy, ponieważ potrafi się zdystansować wobec rzeczywistości. Kiedy Wilczur po latach w rozmowie z Prokopem Mielnikiem ${ }^{4}$ wypowiada słowa: "Nikt nie ma bliskich" (Z, s. 63), w gruncie rzeczy jest już po stronie Obiedzińskiego; zdaje sobie sprawę z marności i względności tego, co nas otacza.

Dwie zacytowane wyżej wypowiedzi Samuela są jednocześnie bardzo trafną diagnozą stanu Wilczura - opisują proces narastania melancholii, którego punktem zapalnym stało się odejście Beaty. „Rozdarty skafander" głównego bohatera, który ujawnia jego "szczeliny i szparki", to bowiem nic innego jak Freudowska "otwarta rana" - melancholijna reakcja na stratę, utratę obiektu miłości. Jak czytamy w klasycznym już szkicu Żałoba i melancholia, mechanizm jej działania opiera się na trzech przesłankach: utracie obiektu,

${ }^{4}$ Rozmowa ta jest istotna $\mathrm{z}$ punktu widzenia rozwoju psychologicznego bohatera: „- Nie miałbym ukryć się u kogo, bo nikogo bliskiego nie mam. A dlaczegóż nie masz? - A ty masz? - zapytał przybyły. Młynarza to zastanowiło. - Jakże? Mam rodzinę. - Ale jakby, nie daj Boże, wymarła, to znalazłbyś bliskich?... Znalazłbyś życzliwych, serdecznych, co pomogliby ci w biedzie? Nieznajomy mówił jakby z goryczą i patrzył w oczy Prokopowi. - Nikt nie ma bliskich - zakończył, a Mielnik nic na to nie odpowiedział" (Z, s. 63). 
ambiwalencji i regresji libido do ,ja". Pierwsza jest w przypadku profesora Wilczura niezaprzeczalna, przyjrzyjmy się dwóm pozostałym.

Ambiwalencja stanowi, zdaniem Zygmunta Freuda, sprężynę napędową konfliktu melancholijnego ${ }^{5}$, przejawia się zaś niezliczoną liczbą jednostkowych walk o odzyskanie obiektu; „batalii, w których walczą ze sobą miłość i nienawiść: jedna, by oderwać libido od obiektu, druga, by utwierdzić pozycję libido w obliczu tej burzy"6. W powieści świetnie obrazują to monologi wewnętrzne bohatera, który najpierw próbuje oczyścić, usprawiedliwić ukochaną, snując domysły, że na pewno stała się ofiarą oszusta i zwalając winę za jej odejście na wyimaginowanego naciągacza, następnie zaś pogrąża się w bólu, powtarzając raz po raz: „ty podła, podła, podła!” (Z, s. 34). Od tego etapu bardzo szybko przechodzi do stadium samoudręki, nazywa siebie „nienawidzonym mężem” (Z, s. 34) i podświadomie dąży do autodestrukcji. Zapuszczając się $w$ niebezpieczne rejony miasta, pijąc olbrzymie ilości wódki w podejrzanych lokalach $\mathrm{z}$ obcymi ludźmi, kusi los. Jego bogactwo prowokuje do ataku przesiadujących w spelunkach warszawskiej Pragi cwaniaczków. Wilczur zostaje niejako na własne życzenie - okradziony i pobity. Konsekwencje tego wydarzenia - utrata pamięci, konieczność tułaczki, bieda - odzwierciedlają ostatnią przesłankę procesu melancholijnego - regresję libido do ,ja". Freud rekonstruuje ów proces w następujący sposób:

Doszło tu do wyboru obiektu, do związania libido z pewną osobą; w konsekwencji wpływu realnej urazy czy realnego rozczarowania doznanego ze strony ukochanej osoby miał miejsce wstrząs w obrębie tego związku z obiektem. Rezultatem nie było tu normalne wycofanie libido $\mathrm{z}$ danego obiektu i przesunięcie go na nowy obiekt; zaszedł tu inny proces wymagający - jak się wydaje - spełnienia kilku warunków. Okazało się, że obsada obiektu nie jest zbyt oporna, została zlikwidowana, lecz uwolnione $\mathrm{w}$ ten sposób libido nie zostało przesunięte na jakiś inny obiekt - zostało wycofane z powrotem do , ,ja". W owym , ja” nie zostało ono jednak wykorzystane w dowolny sposób - posłużyło do tego, by ustanowić utożsamienie ,ja" z porzuconym obiektem. Cień tego obiektu padł zatem w ten sposób na ,ja”, które można było ocenić z perspektywy specyficznej instancji niczym obiekt, niczym porzucony obiekt. W ten sposób utrata obiektu przekształciła się

${ }^{5}$ Z. Freud: Żałoba i melancholia. W: Idem: Psychologia nieświadomości. Przeł. R. ResZKe. Warszawa 2009, s. 159.

${ }^{6}$ Ibidem, s. 158. 
w utratę „ja”, a konflikt pomiędzy ,ja” i ukochaną osobą przybrał formę konfliktu pomiędzy krytyką ,ja” i ,ja” przekształconym za sprawą utożsamienia7.

Innymi słowy: w wyniku straty ubożeje „ja” Wilczura. Odejście żony powoduje w nim wyrwę - to nie świat, jak w przypadku żałoby, opustoszał, to poczucie własnej wartości głównego bohatera gwałtownie się obniżyło. Lekarz czuje się niezdolny do czegokolwiek, a inkorporacja z obiektem straty prowadzi do nieuświadomionego dążenia do doznania odrzucenia, kary i upokorzenia. Melancholik-Wilczur zdaje się myśleć: skoro nie można ukarać samej Beaty za odejście i zadany mi ból, ukarzę tę część mnie, która ściśle się z nią łączyła, oddając władzę popędowi śmierci. Pragnie unicestwienia, nie umiera jednak w sensie biologicznym. Pobicie, którego doznaje, daje mu możliwość zamknięcia „starego życia”, odcięcia się od przeszłości. Ciało profesora nie umiera, pamięć - tak.

Amnezja i jej konsekwencje - zdobycie nowej tożsamości i funkcjonowanie w prostej wiejskiej społeczności jako znachor Antoni Kosiba $^{8}$ - pozwala bohaterowi nie mówić o tym, co go spotkało, uniknąć dalszego bólu przy jednoczesnej pielęgnacji straty i celebracji samoponiżenia. Nie zapominajmy, że Beatę dręczyła potęga męża - w liście pożegnalnym pisała przecież do niego: „Męczył mnie i wielki świat, i bogactwo, i Twoja sława i - moja nicość przy Tobie". Przeistoczenie się z chirurga o międzynarodowej sławie w peryferyjnego zielarza, przeniesienie do świata ludzi prostych, gdzie ani wielki świat, ani bogactwo nie mają dostępu, jest w tej sytuacji nieświadomą reakcją na zarzuty żony, próbą unieważnienia samego siebie, a sprowokowana nieodpowiedzialnym zachowaniem amnezja, niejakie „proszenie się o guza” - wybawieniem, odcięciem się od cierpienia i wspomnieńn . Niemożność przepracowania pustki

7 Ibidem, s. 151-152.

${ }^{8}$ Monografista Mostowicza, Józef Rurawski, dostrzega tutaj charakterystyczny dla pisarza zabieg „niebycia sobą”, „swoistej śmierci bohatera czy też transformacji jego dotychczasowej osobowości". Wilczur jako jedyny z kręgu takich postaci, jak: Nikodem Dyzma, Alicja Horn, Paweł Dalcz, Magda Nieczajówna, dr Murek wraca jednak do sytuacji wyjściowej - odzyskuje pamięć i dawne życie. Por. J. Rurawski: Tadeusz Dołęga-Mostowicz. Warszawa 1987, s. 312-317.

9 Sam bohater pomyśli nawet po latach: „[...] czyż utrata pamięci wówczas nie była [...] dobrodziejstwem? Czyż nie powinien błogosławić Boga za to, że odebrał mu świadomość przeszłości, świadomość śmiertelnej rany zadanej $\mathrm{w}$ serce, w nieprzytomnie kochające serce, przez kobietę, przez ponad wszystko kochaną kobietę...?" (PW, s. 253). 
po utracie przedmiotu miłości prowadzi do zamknięcia go w „wewnętrznej krypcie psychiki", inkorporacji właśnie ${ }^{10}$.

Sprowadza się ona - w odróżnieniu od introjekcji, polegającej na przepuszczeniu bólu przez język, co ma doprowadzić do zrozumienia i pogodzenia się z nieobecnością przedmiotu - do uniknięcia konieczności wypowiedzenia bolesnych słów. Jak czytamy w szkicu Roussel i Wenecja. Zarys geografii melancholicznej:

Słowa te wiążą się z utratą ukochanego przedmiotu, którego istnienie było dla podmiotu, dla jego dobrego samopoczucia (a właściwie narcyzmu) niezbędne. Przedmiot, którego utraty nie chce się uznać, trwa nadal - obok niewyrażonych działań, uczuć i słów w sekretnym systemie typologicznym, głęboko złożony w krypcie psychiki. Inkorporacja jest więc odmową żałoby ${ }^{11}$.

To samo stanowisko przyjmuje Julia Kristeva: melancholia to dla niej załamanie i kryzys języka, a więc porządku symbolicznego ${ }^{12}$. U Wilczura przyjmuje formę skrajną: odmowy przepracowania straty przez zepchnięcie dręczących wspomnień i utraconego obiektu do nieświadomości. Żałoba to pamiętanie przez słowo, powrót do zachowanych pamiątek, fotografii; droga do zapomnienia przez symbolizację i metaforyzację, wpisujące stratę w porządek świata. Melancholia jest zaś odmową pamięci, przepuszczenia wspomnień przez język, niezgodą na tkwienie w przestrzeni przywołującej echa przeszłości. W powieści czytamy:

[...] bał się o tym myśleć. Gdy tylko zaczął, ogarniało go dziwne uczucie: jakby zapomniał coś, coś niezmiernie ważnego. I nagle myśli opanowane gorączkowym niepokojem rozbiegały się we wszystkie strony, zbijały się w jakieś pogmatwane kłębowiska, szarpały się rozpaczliwie, jak zwierzęta ogarnięte dziką paniką; wirowały coraz szybciej, bez sensu, bez celu, potem rwały się w strzępy, w jakieś dziwaczne kłaczki, niby bezkształtne, beztreściowe żyjące potworki, zrastały się w wielki motek waty wypełniający całą czaszkę. W takich chwilach doznawał najokropniejszego strachu. Zdawało mu się, że oszaleje, że doznaje obłędu i że

${ }^{10}$ M.P. Markowsкi: Perekreacja. W: G. Perec: Gabinet kolekcjonera. Historia pewnego obrazu. Przeł. M.P. Marкowsкi. Warszawa 2003, s. 97.

${ }^{11}$ H. Mathews, G. Perec: Roussel $i$ Wenecja. Zarys geografii melancholicznej. Tłum. M.P. Markowsкi. „Literatura na Świecie” 2000, nr 3, s. 210.

12 J. Kristeva: Czarne słońce. Depresja i melancholia. Tłum. M.P. Markowsкi, R. RYzińsKi. Kraków 2007. 
jest wobec zbliżającej się katastrofy bezradny, bezsilny i zgubiony. [...] Na próżno całym wysiłkiem woli usiłował wyrwać się z chłonącego bagna. Przestać myśleć, skupić uwagę na jakimś przedmiocie, ratować się. Jedynie fizyczny ból przynosił lekką ulgę. Wpijał zęby do krwi w ciało, gryzł ręce i tłukł głową o ścianę aż do utraty sił, do omdlenia. Wtedy leżał bezwładny i do ostateczności wyczerpany, niemal martwy. Toteż bał się, bał się obrzydliwym, zwierzęcym lękiem swojej pamięci. Bał się wszystkiego, co go mogło pobudzić do niebacznego zajrzenia w mgłę przeszłości, w ten koszmarny mrok, którego niepodobna przeniknąć, a który przyciąga jak otwarta przepaść.

Z, s. 52

Ostatecznie dochodzi jednak do konieczności zmierzenia się z sobą samym - ze stratą Beaty, bolesnymi wspomnieniami, pogrzebanymi uczuciami. W chwili gdy znachor staje nad grobem matki Marysi - ukochanej panienki sklepowej, którą ratował kosztem więzienia - odzyskuje pamięć. Uświadamia sobie, że dziewczyna to jego własna córka, a mogiła znajdująca się przed nim kryje w sobie zwłoki żony, która opuściła go przed trzynastoma laty. Zaczyna płakać, doznaje oczyszczenia, przebacza krzywdę. Tak jakby rzeczywista śmierć robiła miejsce żałobie, unieważniając melancholię. Beacie już nie jest potrzebna krypta pamięci bohatera - spoczywa w grobie, a on sam może się wreszcie ze stratą pogodzić. Pojawia się miejsce na wybaczenie. Śmierć, zgodnie ze słowami Wiktora Szkłowskiego o Annie Kareninie, godzi wszystkich $\mathrm{z}$ występnymi bohaterami ${ }^{13}$. Narrator Znachora relacjonuje:

Była to zwykła wiejska mogiłka z niewielkim czarnym krzyżykiem zawieszonym zeschniętymi wianuszkami i do połowy zasypanym śniegiem. [...] Antoni powiódł po niej wzrokiem i przeczytał: „Śp. Beata z Gontyńskich...”. Zrobił krok naprzód, wyciągnął ręce przed siebie... [...]

- Boże! - jęknął znachor. W jego mózgu z przeraźliwą jasnością odżyło wszystko. Trząsł się na całym ciele, a z jego gardła wydobywał się jakiś głuchy, nieludzki jęk. Siły opuściły go zupełnie [...]. Skulony na klęczkach w śniegu, z rękami przyciśniętymi do twarzy, nie ustawał w łkaniu. [...] Łzy przynosiły widocznie znachorowi ulgę. Podniósł się ciężko z ziemi, lecz nie odchodził. Marysia podbiegła doń i przytuliła twarz do jego ramienia. Nie widziała nic, bo łzy zalewały jej oczy, lecz słyszała jego cichy głos:

13 J. Rurawski: Tadeusz Dołęga-Mostowicz..., s. 329. 
- Wieczne odpoczywanie racz jej dać, Panie...

Zachodziło słońce, czerwienią i złotem jarzyło się niebo na widnokręgu, na śniegu kładły się niebieskawe cienie, pierwsze muśnięcie wczesnego zimowego zmierzchu.

Przyroda odgrywa tu rolę niebagatelną - w chwili odejścia Beaty mamy do czynienia z jesiennymi dżdżami, błotnistym schyłkiem października, a jak wiadomo już od starożytności: „czarna żółć albo melancholia naśladuje ziemię, przybiera jesienią i dominuje w wieku dojrzałym"14. Nadchodząca po niej zima przynosi ukojenie, czerwono-złoty zmierzch stanowi doskonałe tło dla przebaczenia, umożliwia schłodzenie rany. Nie bez znaczenia jest też upływ czasu - Wilczur już nie ma lat 44, nie znajduje się w „melancholijnym przedziale" wieku ${ }^{15}$. Zamienił się w 57-letniego mężczyznę, zima jest więc także metaforą nadchodzącej starości, sprzyjającej wybaczaniu. Cytując fragment drugiej części dylogii: „Popiół czasu przyprószył przeszłość, popiół czasu przyprószył włosy...” (PW, s. 253). Wszystkie rany tytułowego bohatera są zabliźnione.

Mostowicz za pomocą dramatycznej historii profesora Wilczura dostarcza odbiorcy, głównie mieszczańskiemu, tekst „ku pokrzepieniu serc”, mający "przywracać czy też umacniać wiarę w ludzi, ich dobroć i uczciwość"16. Nie tylko kuruje więc pogrążonego w amnezji chirurga, lecz także serwuje swoisty okład z jego ozdrowienia swoim czytelnikom. Jak głosi nota na okładce pierwszego książkowego

${ }^{14}$ Melancholia w medyczno-przyrodniczej literaturze antyku. W: R. KLIBANSKY, E. PANofsky, F. SAXL: Saturn i melancholia. Studia z historii, filozofii, przyrody, medycyny, religii oraz sztuki. Przeł. A. KryczyńsKa. Kraków 2009, s. 25. Należy oczywiście odróżnić stan psychiczny od rodzaju temperamentu, w przypadku bohatera Mostowicza obydwie perspektywy się jednak przenikają.

${ }^{15}$ Ibidem, s. 31: „Prawdopodobnie już pitagorejczycy powiązali cztery pory roku z czterema etapami ludzkiego życia. [...] Kolejnym logicznym krokiem było przypisanie każdemu z czterech etapów życia jednego z czterech soków (później temperamentów); przyporządkowanie, które przez długie wieki pozostawało w mocy oraz okazało się kluczowe dla dalszej ewolucji myśli teoretycznej i wyobrażeń plastycznych". Zgodnie z tym podziałem okres między 40. a 60. rokiem życia pozostawał we władaniu czarnej żółci i, co ciekawe, rozpoczynał się „nowym dzieciństwem”. Czym innym są swoiste „ponowne narodziny" głównego bohatera w trzecim rozdziale powieści Mostowicza po trzytygodniowym areszcie (magiczna cyfra "trzy" odgrywa tu istotną rolę), jego przeobrażenie się z Rafała Wilczura w Antoniego Kosibę, jak nie powrotem do punktu wyjścia właśnie, symbolicznym „nowym dzieciństwem”?

${ }^{16}$ J. Rurawski: Tadeusz Dołęga-Mostowicz..., s. 307. 
wydania sprzed ponad osiemdziesięciu lat - powieść przenosi czytelnika w "świat ludzi dobrych"17. Można by rzec, że jest lekarstwem na społeczne niepokoje schyłku lat 30 . XX wieku oraz że realizowana jest za jej pomocą kompensacyjna funkcja literatury, o której Paweł Dybel, posiłkując się koncepcją Simona O. Lessera, pisze:

[...] to, co na poziomie dzieła sztuki jawi się jako trauma, postępujący coraz bardziej rozpad świata, znajduje $w$ formie rodzaj przeciwwagi, jako że ta przepaja ów świat głębokim ładem i harmonią. W rezultacie dzieło sztuki doświadczane jest przez odbiorcę jako dynamiczna, pełna wewnętrznych napięć całość, która go ogarnia i porywa, sprowadzając nań katharsis. Forma ma też bardziej ogólne i trudniejsze zadanie: przenieść nas w świat życia, miłości, ładu, wszystkich tych wartości, które drogie są naszemu superego, i w ten sposób stłumić ten nurtujący niepokój, który nas nigdy nie opuszcza i prawie zawsze przewyższa niepokój wywołany daną opowieścią ${ }^{18}$.

W przypadku omawianych powieści Mostowicza ukojenie z pewnością przynosi happy end, pozytywne rozwiązanie wszystkich wątków utworów, przede wszystkim zaś głównego, zasadzającego się na historii dobrego i pracowitego człowieka, który po latach odzyskuje ukochaną córkę, tożsamość i spokój. Budująca jest także zaprezentowana wizja wsi, prowincji, „ziemi, gdzie prawda tak bezpośrednio przemawia do człowieka" (Z, s. 226). Wilczura wszystkie krzywdy spotykają w mieście, charakteryzowanym jako potwór; na wsi zaś, od prostych ludzi, doznaje dobroci. Postępujący antyurbanizm Dołęgi, charakterystyczna dla literatury drugiej dekady dwudziestolecia między wojennego niechęć popularnym jeszcze dziesięć lat wcześniej "trzem M", ma dla odbiorcy wymiar konsolacyjny - okazuje się, że istnieje gdzieś przestrzeń arkadyjska, azyl dla wartości moralnych. Świat inny niż ten znany z ulic i pierwszych stron gazet - taki do rany przyłóż. Jest to świat serca - nie „szkiełka i oka”. Jego dwoistość, rozdarcie uosabia natomiast postać głównego bohatera, który spod władzy rozumu, nauki, pewności i autorytetów przechodzi do sfery wiedzy potocznej, w której królują intuicja, przeczucie, kruchość i tajemnica. Jego "rozdarty skafander" to zatem nie tylko „otwarta rana" - to także pęknięcie, dające możliwość wglądu w - tak typowy dla literatury w wersji pop - dualizm świata przedstawionego.

17 Ibidem.

18 P. Dyвel: Psychoanaliza i literaturoznawstwo. W: Psychoanaliza i literatura. Red. P. Dyвel, M. GŁowiński. Gdańsk 2001, s. 14-15. 


\section{Bibliografia}

DoŁęGa-Mostowicz T.: Znachor. Profesor Wilczur. Łódź 1988.

Dybel P.: Psychoanaliza i literaturoznawstwo. W: Psychoanaliza i literatura. Red. P. Dyвel. M. GŁowiński. Gdańsk 2001, s. 5-27.

Freud Z.: Żałoba i melancholia. W: Idem: Psychologia nieświadomości. Przeł. R. ReszKe. Warszawa 2009, s. 146-161.

Klibansky R., Panofsky E., Saxl F.: Saturn i melancholia. Studia z historii, filozofii, przyrody, medycyny, religii oraz sztuki. Przeł. A. KryczyńsKa. Kraków 2009.

Kristeva J.: Czarne stońce. Depresja i melancholia. Tłum. M.P. Markowski, R. RyziŃsKi. Kraków 2007.

Mathews H., Perec G.: Roussel i Wenecja. Zarys geografii melancholicznej. Tłum. M.P. Markowski. „Literatura na Świecie” 2000, nr 3, s. 203-224.

Markowski M.P.: Perekreacja. W: G. Perec: Gabinet kolekcjonera. Historia pewnego obrazu. Przeł. M.P. Markowsкi. Warszawa 2003, s. 67-179.

Rurawski J.: Tadeusz Dołęga-Mostowicz. Warszawa 1987.

Rurawski J.: Wstęp. W: T. DoŁęGa-Mostowicz: Znachor. Profesor Wilczur. Łódź 1988, s. 5-19.

Sabina Kwak - doktor nauk humanistycznych. Jej zainteresowania badawcze koncentrują się na kulturze i literaturze okresu międzywojennego oraz historii psychoanalizy w Polsce. Opublikowała książkę Dziewictwo i perwersja. O baśniach erotycznych Witolda Gombrowicza (Katowice 2012) oraz liczne artykuły w prasie literaturoznawczej i książkach zbiorowych.

e-mail: sabkwa@gmail.com 